Proc. Estonian Acad. Sci. Biol. Ecol., 2003, 52, 4, 394-406

\title{
Dynamics of Marenzelleria viridis (Polychaeta: Spionidae) pelagic larvae in Pärnu Bay, NE Gulf of Riga, in 1991-99
}

\author{
Mart Simm $^{\mathrm{a}^{*}}$, Henn Kukk ${ }^{\mathrm{a}, \mathrm{b}}$, and Markku Viitasalo ${ }^{\mathrm{c}}$ \\ ${ }^{\text {a }}$ Estonian Marine Institute, University of Tartu, Mäealuse 10A, 12618 Tallinn, Estonia \\ b Tallinn Pedagogical University, Narva mnt. 25, 10120 Tallinn, Estonia; henn@ @pu.ee \\ ${ }^{c}$ Finnish Institute of Marine Research, P.O. Box 33, FIN-00931 Helsinki, Finland; \\ markku.viitasalo@fimr.fi
}

Received 21 October 2002, in revised form 29 November 2002

\begin{abstract}
Marenzelleria viridis, a polychaete species originating from North America, was found in the Baltic Sea in 1985 and in the Gulf of Riga in 1988. In Pärnu Bay, the NE Gulf of Riga, pelagic larvae of Marenzelleria were first discovered in 1991 and have since then been annually present in the plankton community. The abundance of larvae remained relatively constant during the first 6 years, but increased abruptly in 1998-99. This interval between the recording of the first larvae and mass development of the species is extraordinarily long for the Baltic, and was possibly caused by the low salinity of Pärnu Bay. In the North and Baltic seas, two sibling species of Marenzelleria have been identified. The North Sea form, M. cf. wireni, breeds in spring, while the Baltic Sea form, $M$. cf. viridis, has only been reported to breed in autumn. In Pärnu Bay, fertilized eggs and trochophores of Marenzelleria occurred in plankton both in spring and in autumn, which raises a question of the identification of the spring larvae. Earlier genetic analyses have however indicated that only M. cf. viridis is found in the Gulf of Riga. Therefore the species is, in suitable environmental conditions, capable of reproducing two times a year. The spawning season of the Baltic $M$. cf. viridis is thus not genetically determined, but is caused by exogenous factors, such as temperature and possibly also food conditions.
\end{abstract}

Key words: Marenzelleria viridis, introduced species, reproduction, pelagic larvae, Gulf of Riga, Baltic Sea.

\section{INTRODUCTION}

Unintentional introductions of coastal marine species to new environments have increased during the past few decades, mainly due to increasing maritime traffic. The Baltic Sea is especially receptive to invadings since it is shallow and is characterized by various coastal habitats - archipelagoes, estuaries, bays, and

\footnotetext{
* Corresponding author, mart@klab.envir.ee
} 
semi-enclosed lagoons - as well as different bottom types, from mud, sand, and gravel to rocky shores. In addition, the high productivity, low salinities (mainly below 7 PSU), and relatively high summer temperatures make the Baltic prone to newcomers from estuaries and coastal seas of the world. Also, due to the short age of its present brackish-water stage, the post-glacial recolonization of the Baltic Sea by benthic species is probably still going on (Leppäkoski, 1984, 1991).

Well-known examples of nonindigenous invertebrate species in the Baltic include the soft-shelled clam Mya arenaria (introduced in the 12th century from North America; Leppäkoski, 1984), the zebra mussel Dreissena polymorpha (first observations in 1824), the North American barnacle Balanus improvisus (in 1844) and, more recently, the Ponto-Caspian mysid Hemimysis anomala (in 1992; Salemaa \& Hietalahti, 1993) and the cladocerans Cercopagis pengoi (in 1992; Ojaveer \& Lumberg, 1995; Gorokhova et al., 2000). However, probably the most successful recent invader in the Baltic Sea is the spionid polychaete Marenzelleria viridis. Originally inhabiting North American east coast estuaries, Marenzelleria has been found in the North Sea (Essink \& Kleef, 1988, 1993; McLusky et al., 1993) and the southern Baltic estuaries since 1985 (Bick \& Burckhardt, 1989; Bochert \& Bick, 1995). The succeeding years witnessed its rapid spread all over the Baltic Sea (Norkko et al., 1993; Kotta \& Kotta, 1998) including the eastern Gulf of Finland and the Gulf of Bothnia (Stigzelius et al., 1997).

After introduction all newcomers must first colonize their immediate surroundings, then adapt to the environment, reproduce, and establish a population in the new habitat (Leppäkoski et al., 1999). The success of the species however depends on its ability to spread from the site of its primary introduction. Common to many successful invaders is a planktonic stage in their life cycle, which allows the population to spread efficiently. As for Marenzelleria, the long larval development (4 to 12 weeks) also makes the species prone to transportation within the ballast water of ships (Bochert \& Bick, 1995).

After its introduction to Europe, the species was first identified as Marenzelleria viridis (Verrill, 1873). However, differences in the spawning time of Marenzelleria in the North Sea and the Baltic Sea gave rise to the immigrant's identification problems. In the North Sea, Marenzelleria was shown to reproduce in spring (Essink \& Kleef, 1993), while in the southern Baltic breeding was only observed from September to November (e.g. Bochert, 1997). Based on genetic analysis, two sibling species were separated in Marenzelleria viridis: Type I, inhabiting the North Sea, and Type II, inhabiting the Elbe River estuary and the Baltic Sea (Bastrop et al., 1995, 1997; Röhner et al., 1996; Jürss et al., 1999). Bick \& Zettler (1997) also concluded that the morphological features of the adults allow a differentiation of the sibling species as Marenzelleria cf. wireni (Type I) and $M$. cf. viridis (Type II).

In the Gulf of Riga Marenzelleria was for the first time found in 1988 near the Daugava River estuary (Lagzdins \& Pallo, 1994). The abundance and occurrence of adults has since increased in this area (Lagzdins \& Pallo, 1994; Cederwall \& Jermakovs, 1999; Cederwall et al., 1999). Notably, in Pärnu Bay, Marenzelleria larvae have been found both in spring and autumn. 
The abundance of pelagic larvae of Marenzelleria is a good indicator of the distribution and development of the species in new habitats. The present paper gives data on the occurrence of Marenzelleria larvae in the plankton of Pärnu Bay, NE Gulf of Riga, in 1991-99. The objective is to analyse the life cycle of Marenzelleria from the viewpoint of the pelagic stages and to clarify questions regarding their taxonomy and reproduction in the area.

\section{MATERIAL AND METHODS}

\section{Study area}

Pärnu Bay is a shallow area in the NE part of the Gulf of Riga. The bay can be divided into inner and outer parts, separated by the Liu-Tahku line (Fig. 1). The

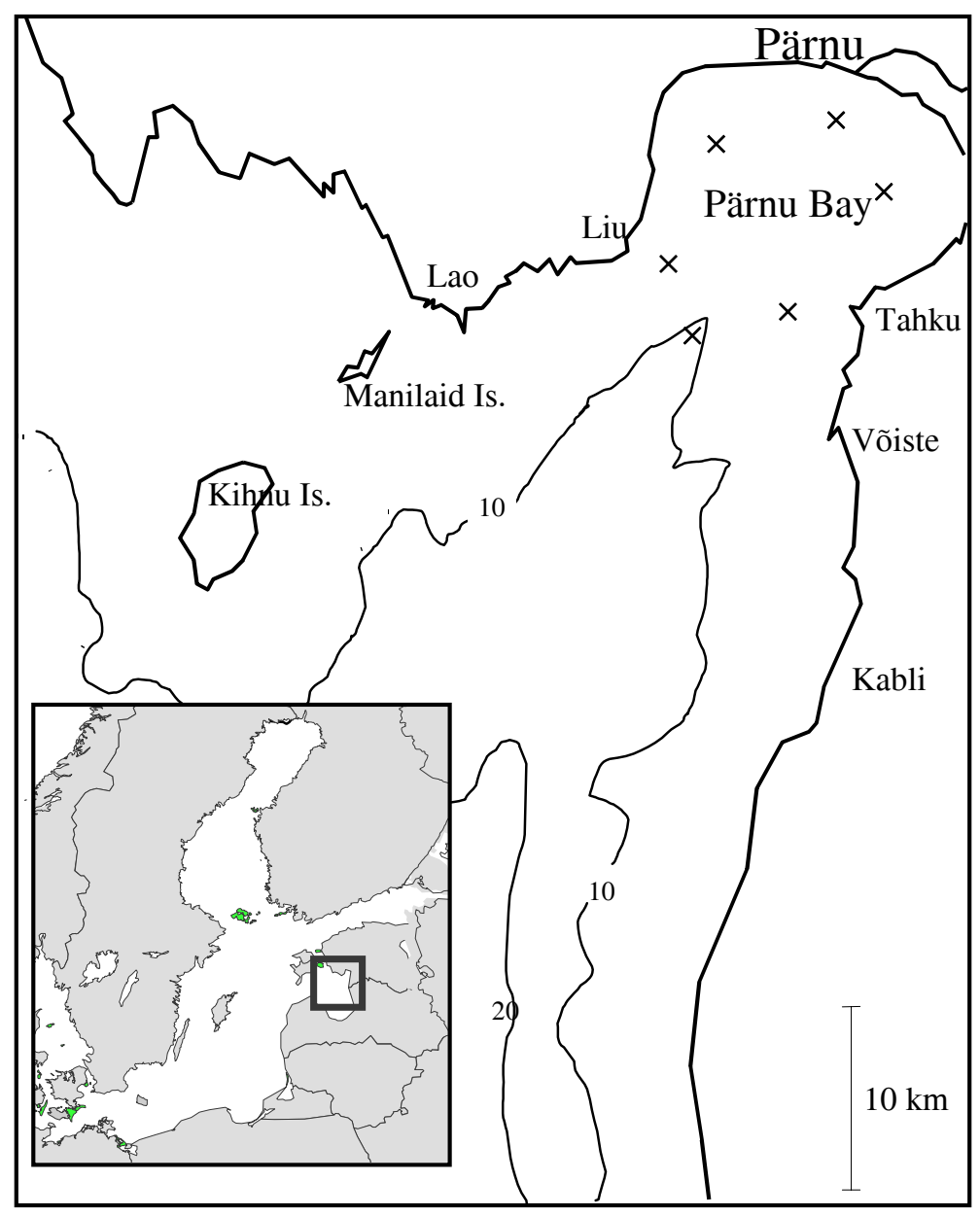

Fig. 1. The study area with the sampling sites. 
maximum water depth in the inner part is $7.5 \mathrm{~m}$ (average $3.5 \mathrm{~m}$ ) and in the outer part, $23 \mathrm{~m}$. The volume of the bay (NE of the Manilaid-Kabli line) is $0.7 \mathrm{~km}^{3}$. A total of $1.75 \mathrm{~km}^{3}$ of fresh water is annually supplied by the Pärnu River. Currents are generally weak $\left(0.06-0.07 \mathrm{~m} \mathrm{~s}^{-1}\right)$, and they depend on the wind direction and speed. After the ice melts, the water temperature rises quickly, exceeding $10^{\circ} \mathrm{C}$ at the end of May. In July and August the temperature of surface water is over $20^{\circ} \mathrm{C}$, and usually remains above $10^{\circ} \mathrm{C}$ until mid-October. Salinity in the bay varies usually between 4 and 5.5 PSU, except during the spring flood in April, when it declines to 2-3 PSU. The water transparency, visually determined by Secchi disc, is low (usually from 0.8 to $2 \mathrm{~m}$ ); the visibility depends on the water depth and wind speed, with strong winds resuspending sediment especially in the shallower areas.

\section{Sampling and analysis}

Mesozooplankton of Pärnu Bay has been collected since the 1950s with a Juday plankton net $(\varnothing 38 \mathrm{~cm}$, mesh size $90 \mu \mathrm{m})$ with vertical hauls from the bottom to the surface. The samples have been preserved in $4 \%$ formalin solution and analysed under a binocular microscope. The present paper is based on data obtained during the 1990s, when samples were collected weekly (from the beginning of April to the end of November) at six stations (Fig. 1). All mesozooplankton taxa have been identified, but in this paper only results on Marenzelleria and total zooplankton abundances are presented. In the analysis the data were combined to show the average abundances of zooplankton in the inner and outer parts of the bay.

In the zooplankton samples the meroplankton - pelagic larvae of Bivalvia, Cirripedia, Gastropoda, and Polychaeta - were also counted. Before the 1990s polychaete larvae (probably Hediste diversicolor and Pygospio elegans) were only occasionally found in July-August. Since 1991 larvae of Marenzelleria have been present in spring and autumn. Since 1999 the younger (fertilized eggs, pre-trochophore, trochopore) and older (setiger) stages of Marenzelleria larvae have been counted separately.

At the stations water temperature was measured in the surface and bottom layers. The runoff data for the Pärnu River were obtained from the Estonian Hydrometeorological Institute.

\section{Statistical analysis}

Correlation analysis was used to study the relationship between water temperature (average for measurements at 1 and $10 \mathrm{~m}$ depths) and the abundance of Marenzelleria larvae in 1992-99. The introduction year 1991 was left out of the analysis. The abundance data for the larvae in the inner and outer parts of 
the bay were first $\log _{10}(x+1)$-transformed, then both time series were seasonally decomposed to remove the seasonal signal, and Pearson correlations were calculated between these transformed time series. Three periods were analysed separately: (1) the whole period ( $n=248$, April-December each year), (2) spring (from April to June; $n=64$ ), and (3) autumn (from September to November; $n=72$ ). The time series transformations and correlation analysis were made with Systat 5.03 statistical package.

An identical analysis was performed with Marenzelleria larval abundance and runoff data for the Pärnu River. The amount of river runoff serves here as a proxy for water salinity as salinity data were not available for Pärnu Bay.

\section{RESULTS}

\section{Occurrence of Marenzelleria larvae in Pärnu Bay}

In the zooplankton of Pärnu Bay pelagic larvae of Marenzelleria first occurred in the outer part of the bay in spring 1991 (Fig. 2). The abundance of larvae was relatively low (ca. 600 ind. $\mathrm{m}^{-3}$; Table 1). Since then, Marenzelleria larvae have been annually present in Pärnu Bay.

In the 1990s Marenzelleria larvae did not show any clear abundance trend in the two study areas (Fig. 2). However, in the latest study years the abundance has been high. In the inner part of the bay the average abundance was the highest in 1998 (11 600 ind. $\mathrm{m}^{-3}$ in spring and 38900 ind. $\mathrm{m}^{-3}$ in autumn), in the outer part in 1999 (21 300 ind. $\mathrm{m}^{-3}$ and 26000 ind. $\mathrm{m}^{-3}$, respectively; Table 1).

Table 1. Mean abundance of Marenzelleria larvae $\left(10^{3}\right.$ ind. $\mathrm{m}^{-3}$; avg $\left.\pm \mathrm{SE}\right)$ in the inner and outer parts of Pärnu Bay in spring and autumn of the 1990s

\begin{tabular}{c|c|c|c|r}
\hline \multirow{2}{*}{ Year } & \multicolumn{2}{|c|}{ Spring (April-June) } & \multicolumn{2}{c}{ Autumn (September-November) } \\
\cline { 2 - 5 } & Inner part & Outer part & Inner part & Outer part \\
\hline \multirow{2}{*}{1991} & 0 & $0.6 \pm 0.1$ & 0 & $6.8 \pm 1.6$ \\
1992 & $1.1 \pm 0.4$ & $0.9 \pm 0.3$ & $0.7 \pm 0.1$ & $3.4 \pm 0.7$ \\
1993 & $0.8 \pm 0.2$ & $3.4 \pm 0.9$ & $1.1 \pm 0.3$ & $1.0 \pm 0.3$ \\
1994 & $2.7 \pm 0.4$ & $1.7 \pm 0.4$ & $8.3 \pm 1.8$ & $5.9 \pm 1.7$ \\
1995 & $1.3 \pm 0.5$ & $0.7 \pm 0.1$ & $6.0 \pm 1.3$ & $3.3 \pm 0.9$ \\
1996 & $7.8 \pm 1.3$ & $2.8 \pm 0.6$ & $9.4 \pm 2.9$ & $5.6 \pm 1.9$ \\
1997 & $2.3 \pm 0.6$ & $1.6 \pm 0.4$ & $1.9 \pm 0.5$ & $2.6 \pm 0.9$ \\
1998 & $11.6 \pm 3.7$ & $0.9 \pm 0.4$ & $38.9 \pm 8.5$ & $12.4 \pm 3.3$ \\
1999 & $12.8 \pm 4.0$ & $21.3 \pm 6.4$ & $10.7 \pm 3.8$ & $26.0 \pm 8.4$
\end{tabular}


Outer part
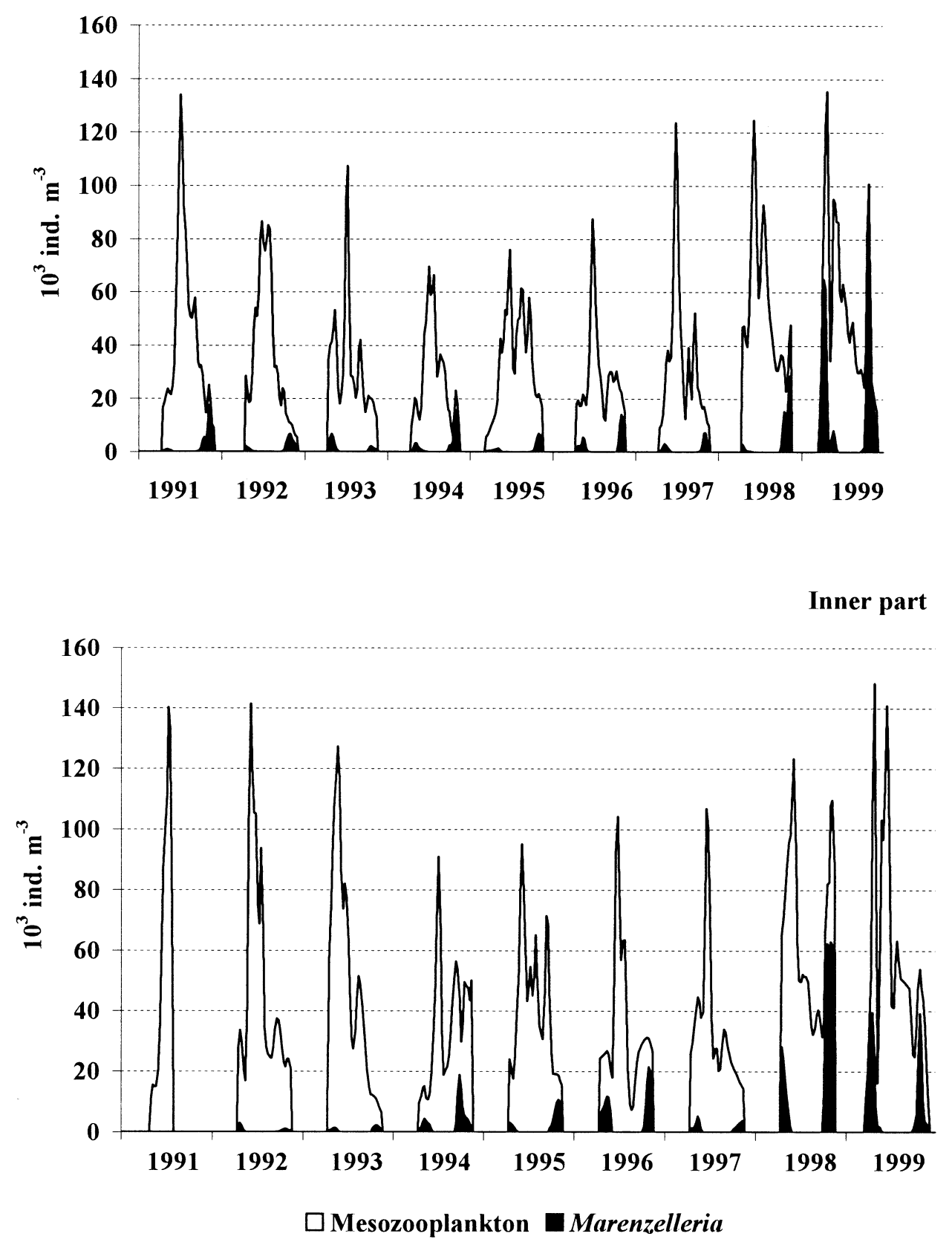

Fig. 2. Abundance of total mesozooplankton and Marenzelleria pelagic larvae in different parts of Pärnu Bay in 1991-99. 
The relative abundance of larvae in the two parts of the bay has varied irregularly: in some years the abundance has been higher in the inner part, in other years in the outer part of the bay. The dominance has also changed during the same year, with higher abundance in the inner part in spring and lower in autumn, and vice versa.

No statistically significant $(p<0.05)$ correlations were found between water temperature and (log-transformed) larval abundance. The runoff from the Pärnu River showed a weak positive correlation $(0.01<p<0.05)$ with the larval abundance in the inner part of the bay (Pearson correlation coefficient $r=0.26$ in spring and 0.24 in autumn) and in the outer part of the bay in spring $(r=0.28)$.

\section{Seasonal succession}

Based on data for 1991-99, the larval abundance dynamics in Pärnu Bay can be summarized as follows. Immediately after ice-melt, few Marenzelleria larvae occur in plankton, and their abundance usually increases rapidly, peaking in April. The larvae disappear in early June and reappear in late September. Their abundance is the highest in late October or early November. In both parts of the bay the abundance of larvae is usually ca. two times higher in autumn than in spring. During the two peaks the water temperature has been very similar, varying from 4.7 to $7.5^{\circ} \mathrm{C}$ in spring and from 4.3 to $7.7^{\circ} \mathrm{C}$ in autumn.

In most years the peaks have occurred almost at the same time in both parts of the bay. Only in 1994 the autumn peak occurred in the inner part in late September and in the outer part of the bay at the beginning of November.

In spring Marenzelleria formed on average 58\% of the pelagic larvae of the bottom fauna, in autumn their share sometimes exceeded 90\%. Of the total mesozooplankton numbers, Marenzelleria larvae contributed on average 8-10\% in spring and $25-30 \%$ in autumn. During their abundance peak, however, they may form 50 to $80 \%$ of all mesozooplankton individuals (Fig. 2).

\section{Larval stages in 1999}

In March 1999 a few older, setiger stages of Marenzelleria were found in the plankton samples. In early April all pelagic stages - fertilized eggs, pretrochophore, trochophore, and setiger stages - occurred in plankton. Younger pelagic stages were present until the end of April. In the outer part of the bay they were more abundant than the setiger stages. In the inner part of the bay the younger stages peaked 1 to 2 weeks later than in the outer part (Fig. 3). 

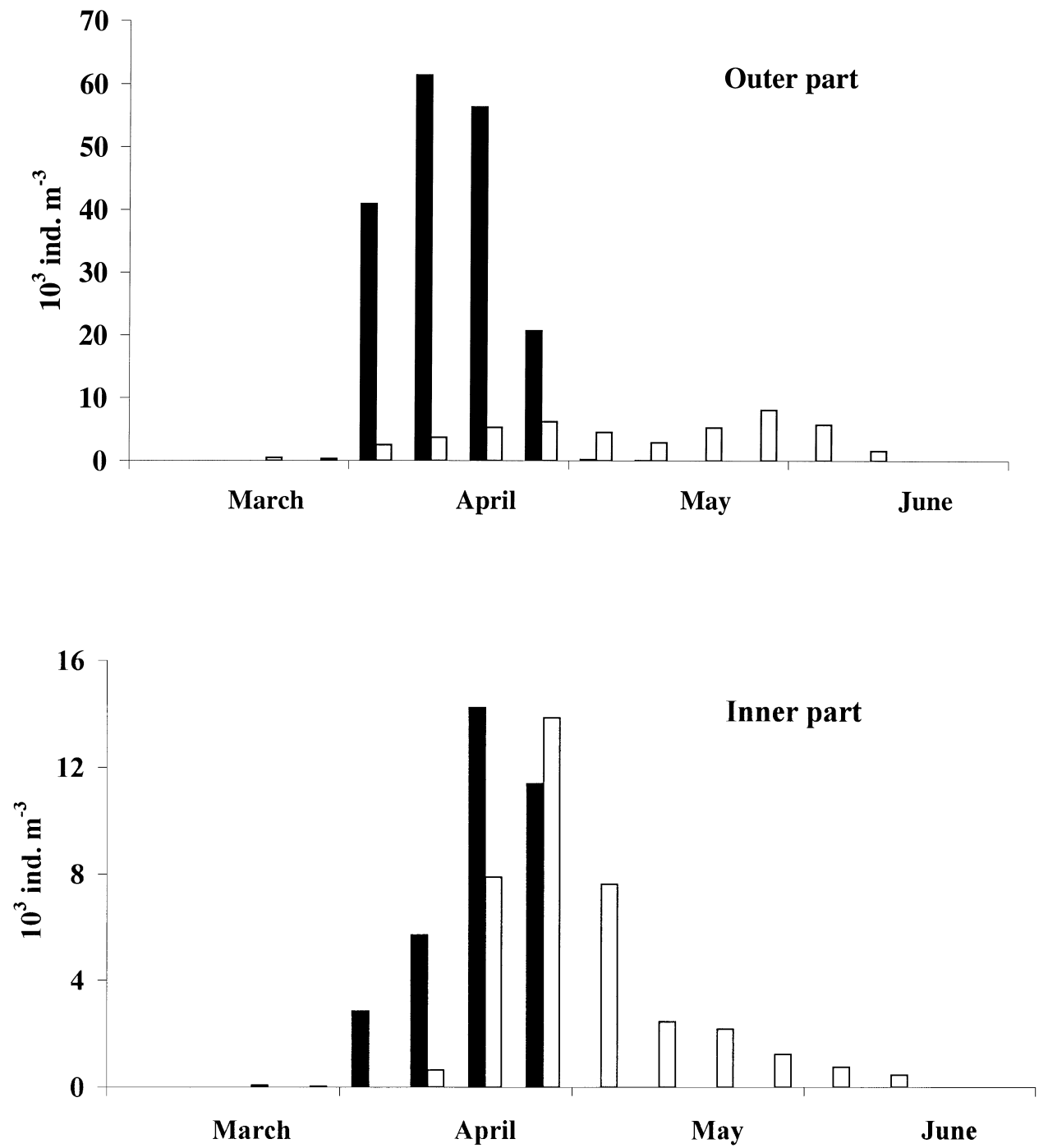

Younger larvae $\square$ Older larvae

Fig. 3. Abundance of Marenzelleria younger (fertilized eggs, trochophores) and older (setiger) larvae in the inner and outer parts of Pärnu Bay in the spring of 1999.

In autumn, starting from October, all pelagic stages, including fertilized eggs, were present in plankton (Fig. 4). The abundances of all stages reached their maxima earlier in the inner part of the bay (in late October) than in the outer part of the bay (in early November). 

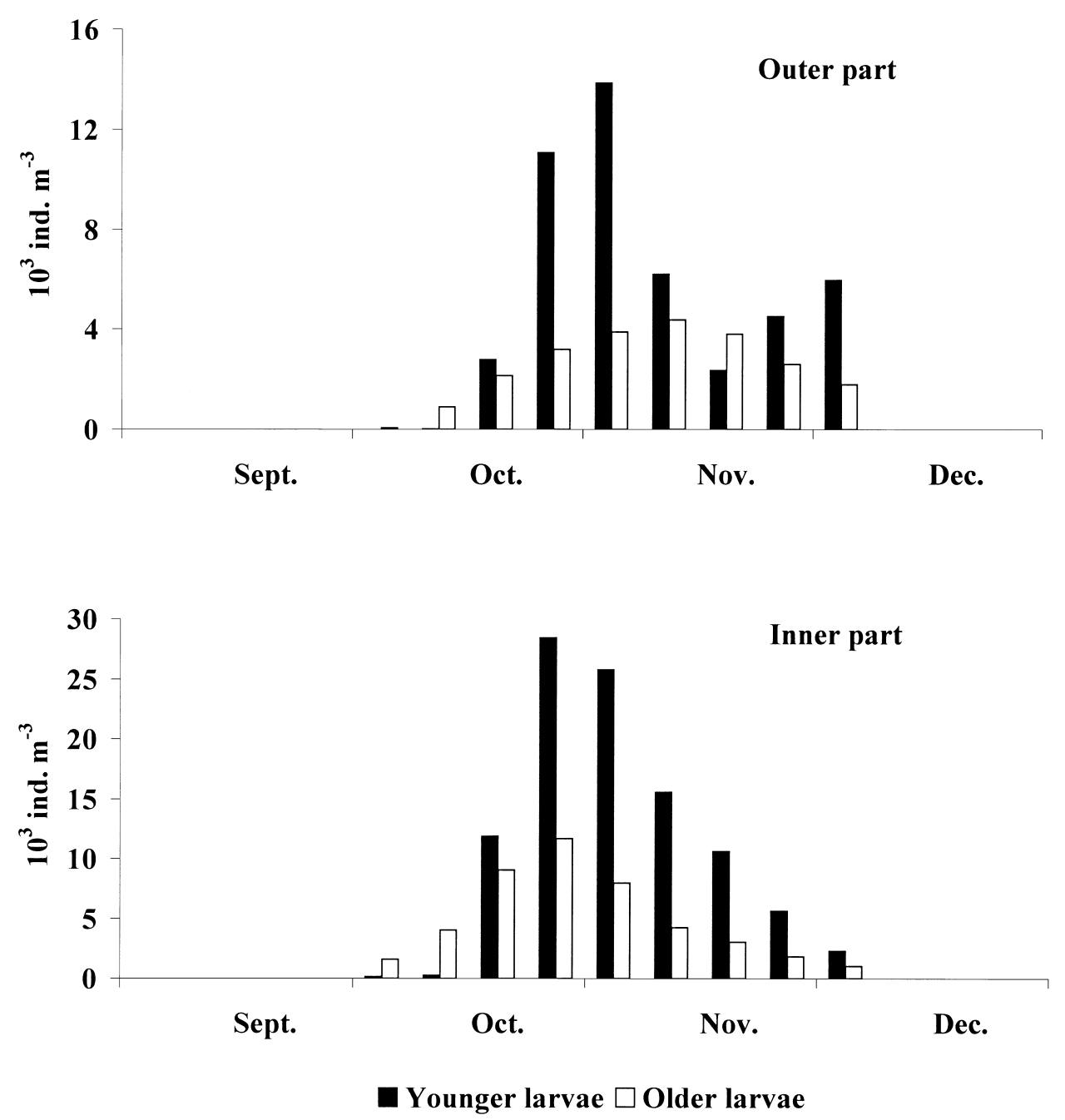

Fig. 4. Abundance of Marenzelleria younger (fertilized eggs, trochophores) and older (setiger) larvae in the inner and outer parts of Pärnu Bay in the autumn of 1999.

\section{DISCUSSION}

\section{Long-term dynamics}

After the first recording of Marenzelleria in the southern Gulf of Riga in 1988, its abundance increased during the four succeeding years (Lagzdins \& Pallo, 1994). In 1994 and 1995, the maximum abundance of Marenzelleria adults in the sediments of the Gulf of Riga exceeded 2000 ind. $\mathrm{m}^{-2}$, the average being ca. 100 ind. $\mathrm{m}^{-2}$ (Kotta \& Kotta, 1998; Pallo et al., 1998; Cederwall \& Jermakovs, 
1999; Ojaveer et al., 1999). In Pärnu Bay a relatively low larval abundance during 1991-97 was followed by a strong increase only in 1998-99 (Fig. 2). Such a long interval between the first record and increase in abundance is unusual for the Baltic Sea. A clear increase in the Marenzelleria abundance is usually observed 2 to 5 years after introduction (Stigzelius et al., 1997; Zettler, 1997). The relatively high temperature and high productivity of the Gulf of Riga should favour larval development in the area (cf. Burckhardt et al., 1997). The slow population increase in Pärnu Bay is thus surprising.

Marenzelleria cf. viridis adults survive in practically fresh water (down to 0.03 PSU) (Fritzsche \& von Oertzen, 1995), but the larval stages are much less tolerant to low salinity. The 3-setiger larval stage is especially vulnerable, since the yolk reserves have been exhausted and the larva starts external feeding. At water salinities below 5 PSU the 3-setiger larvae do not develop further, although, at $5^{\circ} \mathrm{C}$ they may survive for $2-3$ weeks (Bochert, 1997). In Pärnu Bay, especially in its inner part, the salinity of water declines below 5 PSU in spring, which may slow down the development of the spring generation. This may also be the reason for the delayed increase in the larval abundance in Pärnu Bay. This hypothesis could however not be confirmed, since salinity data were not available for Pärnu Bay. It is not clear why the correlations between the runoff data and abundance of Marenzelleria larvae were weakly positive. However, the fraction of explained variance $\left(r^{2}\right)$ was very low $(<8 \%)$, which allows no firm conclusions. It must be noted that statistical analysis of abundance data of an introduced species is very difficult: it is not obvious that any clear relationships can be found between environmental data and the abundance of a species expanding its population in a new habitat. Analysis of larval abundance is especially problematic, since the abundance of larvae at a fixed station depends on reproductive success of adults, advection of larvae with currents, and survival of larvae in the ambient environmental conditions.

\section{Seasonal dynamics}

Based on the occurrence of fertilized eggs and trochophores in plankton it can be concluded that Marenzelleria reproduces in Pärnu Bay both in spring and autumn. In spring spawning starts at ice-melt and continues until late April. In autumn reproduction begins in September and lasts until December. In all likelihood, Marenzelleria does not spawn under ice in winter. This bimodal larval abundance pattern differs from that in other parts of the Baltic Sea, where larvae are mainly found only in autumn (e.g. Bochert \& Bick, 1995; Kube et al., 1996; Bochert, 1997; Daunys et al., 2000).

Differences in spawning times have triggered detailed studies into the taxonomy of Marenzelleria viridis in the North Sea and the Baltic Sea. Bastrop et al. (1997) separated the two groups to different sibling species and proposed that the different spawning seasons are genetically determined. Since in Pärnu Bay Marenzelleria larvae also occur in spring and autumn, both Type I and Type II could be present. However, as Type I apparently prefers a higher salinity than 
occurs in Pärnu Bay (Röhner et al., 1996), and as genetical studies have shown that only M. cf. viridis (Type II) inhabits the Gulf of Riga (Bastrop et al., 1997), we believe that in this bay both larval peaks are produced by the same sibling species $-M$. cf. viridis.

The autumn spawning of Marenzelleria in the southern Baltic Sea was first explained by favourable environmental conditions, mainly temperature (Zettler et al., 1995; Bochert et al., 1996). In the southern Baltic water temperature rises rapidly above $20^{\circ} \mathrm{C}$ in spring. $M$. cf. viridis become sexually mature and reproduce already during their first autumn. In the North Sea estuaries, in contrast, tides cause great variations in water temperature and salinity. Adult Marenzelleria probably use much energy for maintenance, and gametes are not yet fully developed in autumn. By the time the individuals are ready for reproduction, water temperature is already too low for successful larval development. Consequently spawning is delayed until the next spring (Bochert et al., 1996).

In the Gulf of Riga, like in the whole Baltic Sea, tides are absent, but the temperature conditions are somewhat harsher than in the southern Baltic. Water temperature usually rises above $20^{\circ} \mathrm{C}$ only in the middle of July. Nevertheless, in Pärnu Bay the greater part of Marenzelleria population reproduce in autumn. Evidently the species produces several, partly overlapping, generations or cohorts per year. In the southern Gulf of Riga three adult generations (Cederwall \& Jermakovs, 1999) have been distinguished. How these three generations can produce two larval peaks is not obvious. The growth rate and survival of Marenzelleria larvae depend on salinity, temperature, as well as food concentration and quality (Bochert, 1997; Burckhardt et al., 1997). It can be hypothesized that the larvae that are born in early April can utilize the phytoplankton spring bloom and develop rapidly in the warm summer temperatures. Like their conspecifics in the southern Baltic, they mature early and reproduce during their first autumn. In contrast, the larvae that are born later in spring develop slower and their spawning takes place only during the next spring. Detailed life history studies are however needed to establish the reproductive pattern of Marenzelleria $\mathrm{cf}$. viridis in Pärnu Bay.

\section{ACKNOWLEDGEMENT}

This study was financed by the Estonian Governmental Programme No. $0182578 \mathrm{~s} 03$.

\section{REFERENCES}

Bastrop, R., Röhner, M. \& Jürss, K. 1995. Are there two species of the polychaete genus Marenzelleria in Europe? Mar. Biol., 121, 509-516.

Bastrop, R., Röhner, M., Sturmbauer, C. \& Jürss, K. 1997. Where did Marenzelleria spp. (Polychaeta: Spionidae) in Europe come from? Aquat. Ecol., 31, 119-136.

Bick, A. \& Burckhardt, R. 1989. Erstnachweis von Marenzelleria viridis (Polychaeta, Spionidae) für den Ostseeraum, mit einem Bestimmungsschlüssel der Spioniden der Ostsee. Mitt. Zool. Mus. Berlin, 65, 237-247. 
Bick, A. \& Zettler, M. L. 1997. On the identity and distribution of two species of Marenzelleria (Polychaeta, Spionidae) in Europe and North America. Aquat. Ecol., 31, 137-148.

Bochert, R. 1997. Marenzelleria viridis (Polychaeta: Spionidae): a review of its reproduction. Aquat. Ecol., 31, 163-175.

Bochert, R. \& Bick, A. 1995. Reproduction and larval development of Marenzelleria viridis (Polychaeta: Spionidae). Mar. Biol., 123, 763-773.

Bochert, R., Zettler, M. L. \& Bochert, A. 1996. Variation in the reproductive status, larval occurrence and recruitment in an estuarine population of Marenzelleria viridis (Polychaeta: Spionidae). Ophelia, 45, 127-142.

Burckhardt, R., Schumann, R. \& Bochert, R. 1997. Feeding biology of the pelagic larvae of Marenzelleria cf. viridis (Polychatea, Spionidae) from the Baltic Sea. Aquat. Ecol., 31, 149-162.

Cederwall, H. \& Jermakovs, V. 1999. Growth and production of three macrozoobenthic species in the Gulf of Riga, including comparisons with other areas. Hydrobiologia, 393, 201-210.

Cederwall, H., Jermakovs, V. \& Lagzdins, G. 1999. Long-term changes in the soft-bottom macrofauna of the Gulf of Riga. ICES J. Mar. Sci., 56 (Suppl.), 41-48.

Daunys, D., Schiedek, D. \& Olenin, S. 2000. Species strategy near its boundary: the Marenzelleria cf. viridis (Polychaeta, Spionidae) case in the south-eastern Baltic Sea. Int. Rev. Hydrobiol., 85, 639-651.

Essink, K. \& Kleef, H. L. 1988. Marenzelleria viridis (Verrill, 1873) (Polychaeta: Spionidae): a new record from the Ems Estuary (The Netherlands/Federal Republic of Germany). Zool. Bijdr., 38, 1-13.

Essink, K. \& Kleef, H. L. 1993. Distribution and life cycle of the North American spionid polychaete Marenzelleria viridis (Verrill, 1873) in the Ems Estuary. Neth. J. Aquat. Ecol., 27, 237-246.

Fritzsche, D. \& von Oertzen, J. A. 1995. Metabolic response to changing environmental conditions in the brackish water polychaetes Marenzelleria viridis and Hediste diversicolor. Mar. Biol., 121, 76-93.

Gorokhova, E., Aladin, N. \& Dumont, H. 2000. Further expansion of the genus Cercopagis (Crustacea, Branchiopoda, Onychopoda) in the Baltic Sea, with notes on the taxa present and their ecology. Hydrobiologia, 429, 207-218.

Jürss, K., Röhner, M. \& Bastrop, R. 1999. Enzyme activities and allozyme polymorphism in two genetic types (or sibling species) of the genus Marenzelleria (Polychaeta: Spionidae) in Europe. Mar. Biol., 135, 489-496.

Kotta, J. \& Kotta, I. 1998. Distribution and invasion ecology of Marenzelleria viridis in the Estonian coastal waters. Proc. Estonian Acad. Sci. Biol. Ecol., 47, 212-220.

Kube, J., Zettler, M. L., Gosselck, F., Ossig, S. \& Powilleit, M. 1996. Distribution of Marenzelleria viridis (Polychaeta: Spionidae) in the southwestern Baltic Sea in 1993/94 - ten years after introduction. Sarsia, 81, 131-142.

Lagzdins, G. \& Pallo, P. 1994. Marenzelleria viridis (Verrill) (Polychaeta, Spionidae) - a new species for the Gulf of Riga. Proc. Estonian Acad. Sci. Biol. Ecol., 43, 184-188.

Leppäkoski, E. 1984. Introduced species in the Baltic Sea and its coastal ecosystems. Ophelia, Suppl. 3, 123-135.

Leppäkoski, E. 1991. Introduced species - resource or threat in brackish water seas? Examples from the Baltic and the Black Sea. Mar. Pollut. Bull., 23, 219-223.

Leppäkoski, E., Helminen, H., Hänninen, J. \& Tallqvist, M. 1999. Aquatic biodiversity under anthropogenic stress. An insight from the Archipelago Sea (SW Finland). Biodivers. Conserv., 8, 55-70.

McLusky, D. S., Hull, S. C. \& Elliott, M. 1993. Variations in the intertidal and subtidal macrofauna and sediments along a salinity gradient in the upper Forth Estuary. Neth. J. Aquat. Ecol., 27, 101-109.

Norkko, A., Bonsdorff, E. \& Boström, C. 1993. Observations of the polychaete Marenzelleria viridis (Verrill) on a shallow sandy bottom on the south coast of Finland. Mem. Soc. Fauna Flora Fenn., 69, 112-113. 
Ojaveer, H. \& Lumberg, A. 1995. On the role of Cercopagis (Cercopagis) pengoi (Ostroumov) in Pärnu Bay and the NE part of the Gulf of Riga ecosystem. Proc. Estonian Acad. Sci. Ecol., 5, 20-25.

Ojaveer, H., Lankov, A., Eero, M., Kotta, J., Kotta, I. \& Lumberg, A. 1999. Changes in the ecosystem of the Gulf of Riga from the 1970s to the 1990s. ICES J. Mar. Sci., 56 (Suppl.), 33-40.

Pallo, P., Widbom, B. \& Olafsson, E. 1998. A quantitative survey of the benthic meiofauna in the Gulf of Riga (eastern Baltic Sea), with special reference to the structure of nematode assemblages. Ophelia, 49, 119-139.

Röhner, M., Bastrop, R. \& Jürss, K. 1996. Colonization of Europe by two American genetic types or species of the genus Marenzelleria (Polychaeta: Spionidae). An electrophoretic analysis of allozymes. Mar. Biol., 127, 277-287.

Salemaa, H. \& Hietalahti, V. 1993. Hemimysis anomala G. O. Sars (Crustacea: Mysidacea) immigration of a Pontocaspian mysid into the Baltic Sea. Ann. Zool. Fenn., 30, 271-276.

Stigzelius, J., Laine, A., Rissanen, J., Andersin, A.-B. \& Ilus, E. 1997. The introduction of Marenzelleria viridis (Polychaeta, Spionidae) into the Gulf of Finland and the Gulf of Bothnia (northern Baltic Sea). Ann. Zool. Fenn., 34, 205-212.

Zettler, M. L. 1997. Population dynamics, growth and production of the neozoon Marenzelleria $\mathrm{cf}$. viridis (Verrill, 1873) (Polychaeta: Spionidae) in a coastal water of the southern Baltic Sea. Aquat. Ecol., 31, 177-186.

Zettler, M. L., Bick, A. \& Bochert, R. 1995. Distribution and population dynamics of Marenzelleria viridis (Polychaeta, Spionidae) in a coastal water of the southern Baltic. Arch. Fish. Mar. Res., 42, 209-224.

\title{
Marenzelleria viridis'e (Polychaeta: Spionidae) pelaagiliste vastsete arvukuse dünaamika Pärnu lahes aastail 1991-1999
}

\author{
Mart Simm, Henn Kukk ja Markku Viitasalo
}

Põhja-Ameerikast pärinev polüheet Marenzelleria viridis määrati esmakordselt Läänemeres 1985. ja Liivi lahes 1988. aastal. Alates 1991. aastast on Marenzelleria pelaagilised vastsed esinenud igal aastal Pärnu lahe planktonis. Vastsete suhteliselt püsiv arvukus kasvas hüppeliselt aastail 1998-1999. Läänemere puhul erandlikult pikk ajaline vahe liigi ilmumise ja massilise arengu vahel on ilmselt tingitud vee vähesest soolsusest Pärnu lahes. Lääne- ja Põhjameres on määratud kaks erinevat Marenzelleria vormi, paarisliiki. Põhjameres esinev vorm, $M$. cf. wireni, paljuneb kevadel, Läänemere vorm, $M$. cf. viridis, aga sügisel. Pärnu lahes esinevad Marenzelleria viljastatud munad ja trohhofoorvastsed nii kevadel kui ka sügisel. Seega kerkib kevadiste vastsete liigilise kuuluvuse küsimus. Kuna geneetiliste uuringute alusel esineb Liivi lahes vaid $M$. cf. viridis, võib oletada, et sobivates keskkonnatingimustes paljuneb see liik kaks korda aastas. $M$. cf. viridis'e paljunemise aeg ei ole määratud mitte geneetiliselt, vaid see sõltub väliskeskkonna oludest, tõenäoliselt peamiselt vee temperatuurist ja toitumistingimustest. 